\title{
KAJIAN YURIDIS PENELANTARAN ANAK OLEH ORANG TUA MENURUT PERSPEKTIF HUKUM INDONESIA
}

\author{
Oleh : \\ Ardiansyah * \\ Ferdricka Nggeboe *
}

\begin{abstract}
ABSTRAK
Perlindungan hukum terhadap anak korban penelantaran oleh orang tua di Indonesia belum optimal dikarenakan kasus penelantaran anak oleh orang tua masih meningkat. Hal ini disebabkan oleh masih lemahnya system hukum antara lain belum adanya peraturan pelaksanaan yang sangat dibutuhkan untuk menerapkan undang-undang, ketidak jelasan arti kata-kata didalam undang-undang yang mengakibatkan kesimpang siuran di dalam penafsiran dan penerapannya orang tua sendiri yang merupakan pelaku penelantaran, kebanyakan keluarga yang tidak melaporkan kasus ini karena apabila kasus ini tersebar, maka hanya akan menjadi aib bagi keluarga, Sulitnya mendapat keterangan yang sebenar-benarnya dari korban anak, apabila ada orang tua di sisinya, adanya intervensi dari pihak keluarga yang mengintimidasi si Anak sehingga kasus ini seperti ditutup tutupi, kesulitan dalam Reintegrasi, hal ini dikarenakan orang tua tidak mau menerima anak itu kembali di dalam keluarga. Hal ini disebabkan kekecewaan orang tua yang merasa anaknya telah mencemari nama baik keluarga
\end{abstract}

Kata Kunci: Penelantara Anak, Orang Tua, Hukum Indonesia

\section{A. Latar Belakang Masalah}

Anak mempunyai hak yang bersifat asasi, sebagaimana yang dimiliki orang dewasa, hak asasi manusia (HAM). Pemberitaan yang menyangkut hak anak tidak segencar sebagaimana hak-hak orang dewasa (HAM) atau isu gender, yang menyangkut hak perempuan. Perlindungan hak anak tidak banyak pihak yang turut memikirkan dan melakukan langkah-langkah kongkrit. Demikian juga upaya untuk melindungi hak-hak anak yang dilanggar yang dilakukan negara, orang dewasa atau bahkan orang tuanya sendiri, tidak begitu menaruh perhatian akan kepentingan masa depan anak. Padahal anak merupakan belahan jiwa, gambaran dan cermin masa depan, aset keluarga, agama, bangsa dan negara.

Perlindungan yang diberikan terhadap anak harus diberikan secara menyeluruh yang terus diupayakan oleh Pemerintah untuk mewujudkan kesejahteraan masyarakat agar tercipta suasana aman, tentram dan makmur seperti yang tersirat dalam tujuan nasional

\footnotetext{
* Mahasiswa Program Magister Ilmu Hukum Unbari.

* Pengajar Program Magister Ilmu Hukum Unbari.
} 
bangsa Indonesia yang tercantum dalam Pembukaan Undang-undang Dasar 1945 alenia IV yakni mewujdkan masyarakat adil makmur berdasarkan Pancasila dan lebih jelasnya telah diamanatkan dalam Pasal 28B ayat (2) Amandemen Undang-undang Dasar 1945 bahwa :

"Setiap anak berhak atas kelangsungan hidup, tumbuh dan berkembang serta berhak atas perlindungan dari kekerasan dan diskriminasi"

Pertumbuhan dan perkembangan anak amat ditentukan oleh lingkungan di sekitar anak. Lingkungan yang paling dekat dengan anak adalah keluarga terdiri dari ayah dan ibu yang sering dikenal sebagai orang tua. Secara umum dapat diambil pengertian bahwa orang tua atau keluarga adalah:

1. Merupakan kelompok kecil yang umumnya terdiri atas ayah, ibu dan anakanak.

2. Hubungan antar anggota keluarga dijiwai oleh suasana afeksi dan rasa tanggung jawab.

3. Hubungan sosial di antara anggota keluarga relatif tetap dan didasarkan atas ikatan darah, perkawinan atau adopsi.

4. Umumnya orang tua berkewajiban memelihara, merawat, dan melindungi anak dalam rangka sosialisasinya agar meraka mampu mengendalikan diri dan berjiwa sosial ${ }^{1}$.

Orang tua memiliki peranan penting dalam pertumbuhan dan perkembangan anak berupa pendidikan, perhatian, tanggap kebutuhan dan keinginan anak, adanya kasih sayang dan kehangatan orang tua dengan anak. Pendidikan orang tua lebih menekankan pada aspek moral atau pembentukan kepribadian dari pada pendidikan untuk menguasai ilmu pengetahuan, dasar dan tujuan penyelenggaraan pendidikan keluarga bersifat individual, sesuai dengan pandangan hidup orang tua masing-masing, sekalipun secara nasional bagi keluarga-keluarga Indonesia memiliki dasar yang sama, yaitu pancasila. Ada orang tua dalam mendidik anaknya mendasarkan pada kaidah-kaidah agama dan menekankan proses pendidikan pada pendidikan agama dan tujuan untuk menjadikan anak-anaknya menjadi orang yang saleh dan senantiasa takwa dan iman kepada Tuhan Yang Maha Esa, ada pula orang tua yang dasar dan tujuan penyelenggaraan pendidikannya berorientasi kepada kehidupan sosial ekonomi kemasyarakatan dengan tujuan untuk menjadikan anak-anaknya menjadi orang yang produktif dan bermanfaat dalam kehidupan masyarakat.

\footnotetext{
${ }^{1}$ Nursyamsiyah Yusuf, Ilmu Pendidikan, Pusat Penerbitan dan Publikasi, Tulung Agung, 2000, hal. 66
} 
Orang tua merupakan lembaga pendidikan tertua, bersifat informal, yang pertama dan utama dialami oleh anak serta lembaga pendidikan yang bersifat kodrati, orang tua bertanggung jawab memelihara, merawat, melindungi, dan mendidik anak agar tumbuh dan berkembang dengan baik. ${ }^{2}$

Perlindungan hukum terhadap anak diperhatikan serius oleh negara Negara Kesatuan Republik Indonesia dengan memberikan jaminam kesejahteraan, perlindungan terhadap hak anak yang merupakan hak asasi manusia dikarenakan anak merupakan tunas, potensi, dan generasi muda penerus cita-cita perjuangan bangsa memiliki peran strategis, ciri, dan sifat khusus. Negara Indonesia telah memberikan posisi anak dalam peraturan perundang undangan Indonesia yaitu Undang Undang Nomor 23 Tahun 2004 tentang Penghapusan Kekerasan Dalam Rumah Tangga dicantumkan dalam Pasal 2 angka (1), menyatakan :

Pasal 2

(1) Lingkup rumah tangga dalam Undang-Undang ini meliputi:

a. suami, isteri, dan anak;

Hak anak yang memerlukan peranan penting orang tua telah dicantumkan pada Pasal 6 Undang-Undang Republik Indonesia Nomor 35 Tahun 2014 Tentang Perubahan Atas Undang-Undang Nomor 23 Tahun 2002 Tentang Perlindungan Anak, bahwa :

Pasal 6

Setiap Anak berhak untuk beribadah menurut agamanya, berpikir, dan berekspresi sesuai dengan tingkat kecerdasan dan usianya dalam bimbingan Orang Tua atau Wali.

Selanjutnya penelantaran anak oleh orang tua kandung yang menjadi kajian penelitian ini menurut Undang Republik Indonesia Nomor 35 Tahun 2014 Tentang Perubahan Atas Undang-Undang Nomor 23 Tahun 2002 Tentang Perlindungan Anak dikategorikan sebagai kekerasan terhadap anak dikarenakan perbuatan menimbulkan kesengsaraan atau penderitaan secara fisik, psikis, penelantaran, pemaksaan, atau perampasan kemerdekaan secara melawan hukum. sebagaimana dicantumkan Pasal 1 angka 15 (a) dan didalam Pasal 5 Undang Undang Nomor 23 Tahun 2004 Tentang Penghapusan Kekerasan Dalam Rumah Tangga juga dicantumkan larangan melakukan kekerasan terhadap anak yang merupakan anggota dalam lingkup rumah tangga, menyatakan :

\footnotetext{
${ }^{2}$ Binti Maunah, Ilmu Pendidikan, Teras, Yogyakarta, 2009, hal. 92
} 


\section{Pasal 5}

Setiap orang dilarang melakukan kekerasan dalam rumah tangga terhadap orang dalam lingkup rumah tangganya, dengan cara:

a. kekerasan fisik;

b. kekerasan psikis;

c. kekerasan seksual; atau

d. penelantaran rumah tangga.

Negara Indonesia telah mengatur sanksi hukuman bagi pelaku penelantaran anak yang dikategorikan sebagai kekerasan sebagaimana diatur di dalam Undang-Undang No. 35 Tahun 2014 tentang Perubahan Atas Undang-Undang No. 23 Tahun 2002 terkait Perlindungan Anak, sebagai berikut :

Pasal 76 B

Setiap Orang dilarang menempatkan, membiarkan, melibatkan, menyuruh melibatkan Anak dalam situasi perlakuan salah dan penelantaran.

Pasal 77B

Setiap Orang yang melanggar ketentuan sebagaimana dimaksud dalam Pasal 76B, dipidana dengan pidana penjara paling lama 5 (lima) tahun dan/atau denda paling banyak Rp100.000.000,00 (seratus juta rupiah).

dan juga diatur di dalam Undang Undang Nomor 23 Tahun 2004 Tentang Penghapusan Kekerasan Dalam Rumah Tangga, sebagai berikut :

Pasal 44

(1) Setiap orang yang melakukan perbuatan kekerasan fisik dalam lingkup rumah tangga sebagaimana dimaksud dalam Pasal 5 huruf a dipidana dengan pidana penjara paling lama 5 (lima) tahun atau denda paling banyak Rp15.000.000,00 (lima belas juta rupiah).

(2) Dalam hal perbuatan sebagaimana dimaksud pada ayat (1) mengakibatkan korban mendapat jatuh sakit atau luka berat, dipidana dengan pidana penjara paling lama 10 (sepuluh) tahun atau denda paling banyak Rp30.000.000,00 (tiga puluh juta rupiah).

(3) Dalam hal perbuatan sebagaimana dimaksud pada ayat (2) mengakibatkan matinya korban, dipidana dengan pidana penjara paling lama 15 (lima belas) 
tahun atau denda paling banyak Rp45.000.000,00 (empat puluh lima juta rupiah).

Fenomena Penelanataran anak yang terjadi tidak ada satupun kasus yang diproses hukum dalam penegakan hukum terhadap orang tua yang melakukan tindakan penelantaran terhadap anaknya, hal ini merupakan terpuruknya dunia anak di Indonesia. dunia anak yang diharapkan merupakan kegiatan bermain, belajar dan mengembangkan minat serta bakatnya untuk masa depan, realitas diwarnai data kelam dan menyedihkan anak Indonesia masuh terus mengalami kekerasan. secara kebudayaan mereka masih berada di tengah situasi menindas, gambaran tentang anak-anak ideal seperti yang tertera dalam Konvensi Hak Anak masih jauh dari kenyataan, mereka masih menjadi bagian yang terpinggirkan, tereksplorasi, terepresi oleh Lingkungan dan budaya dimana mereja hidup , seperti dalam keluarga, masyarakat pendidikan formal di sekolah dan sector kehidupan lainnya. Modernisasi di negeri ini belum memperhatikan persoalan anak dengan baik justru yang terjadi mereka menjadi korban dari modernitas yang tengah berlangsung ${ }^{3}$.

\section{B. Perumusan Masalah}

Perumusan masalah dalam penelitian ini adalah :

1. Bagaimanakah kebijakan perlindungan hukum terhadap anak korban penelantaran oleh orang tua menurut persfektif Hukum Indonesia?

2. Bagaimanakah analisa yuridis perlindungan hukum terhadap anak korban penelantaran oleh orang tua di Indonesia?

\section{Metodologi Penelitian}

1. Spesifikasi Penelitian

Spesifikasi dalam penelitian ini adalah penelitian deskriptif analitis, yaitu penelitian yang mendeskripsikan secara terperinci fenomena sosial yang menjadi pokok permasalahan. Suatu penelitian diskriptif dimaksudkan untuk memberikan data yang seteliti mungkin tentang korban, keadaan atau gejala-gejala lainnya. ${ }^{4}$

2. Metode Pendekatan

Penelitian tentang kebijakan perlindungan hukum terhadap anak korban penelantaran oleh orang tua dalam perspektip hukum di Indonesia ini menggunakan

\footnotetext{
${ }^{3}$ Abu Huraerah, Kekerasan Anak Terhadap Anak, Nuansa, Bandung, 2006, hal. 15

4 Soerjono Soekanto, Pengantar Penelitian hukum, Jakarta, UI PRESS, 1986, hal. 10.
} 
pendekatan yang bersifat yuridis normatif, yaitu dengan mengkaji/menganalisis data sekunder yang berupa bahan-bahan hukum terutama bahan hukum primer dan bahan hukum sekunder dengan memahami hukum sebagai seperangkat peraturan atau norma-norma positif didalam sistem perundang-undangan yang mengatur mengenai kehidupan manusia.

Penelitian hukum normatif merupakan penelitian yang dilakukan dengan cara meneliti bahan pustaka. Penelitian hukum normatif atau kepustakaan ini mencakup: (1) penelitian terhadap asas-asas hukum; (2) penelitian terhadap sistematika hukum; (3) penelitian terhadap taraf sinkronisasi vertikal dan horizontal; (4) perbandingan hukum; dan (5) sejarah hukum. ${ }^{5}$

Analisis bahan hukum dilakukan dengan meneliti pengertian-pengertian hukum dan norma-norma hukum. Dengan cara melihat isi dari berbagai macam peraturan perundang-undangan yang berhubungan dengan hak-hak korban kejahatan. Penganalisisan terhadap isi bahan hukum dengan melakukan intreprestasi, menilai dan melakukan evaluasi terhadap semua kebijakan hukum pidana yang berhubungan dengan hak-hak korban kejahatan.

\section{Kajian yuridis penelantaran anak oleh orang tua menurut perspektif hukum indonesia}

1. Kebijakan Perlindungan Hukum Terhadap Anak Korban Penelantaran Oleh Orang Tua Menurut Persfektif Hukum Indonesia

Penelantaran anak oleh orang tua merupakan bagian dari kekerasan yang dialami oleh anak. Sehingga menuntut peranan Negara Indonesia melalui hukum yang dimiliki untuk mengatur keamanan terjamin dan adanya perlindungan atas kepentingan tiap-tiap orang (warga Negara), dimana anak-anak yang mengalami penelantaran oleh orang tua merupakan generasi penerus bangsa memiliki hak sebagai warga Negara untuk mencapai kebahagiaan yang merata seperti anak-anak Indonesia lainnya yang tidak mengalami penelantaran oleh orang tua. Hal ini berdasarkan pasal 4 Undang-undang Nomor 12 Tahun 2006 tentang Kewarganegaraan mengatakan, criteria anak yang menjadi Warga Negara Indonesia (WNI) adalah :

\footnotetext{
5 Soerjono Soekanto dan Sri Mamuji, Penelitian Hukum Normatif "Suatu Tinjauan Singkat", Jakarta, PT Raja Grafindo Persada, 2004, hal. 14
} 
1. Anak yang lahir dari perkawinan yang sah dari ayah dan ibu WNI.

2. Anak yang lahir dari perkawinan yang sah dari seorang ayah WNI dan ibu warga Negara asing (WNA), atau sebaliknya.

3. Anak yang lahir dari perkawinan yang sah dari seorang ibu WNI dan ayah yang tidak memiliki kewarganegaraan atau hukum Negara asal sang ayah tidak memberikan kewarganegaraan kepada anak tersebbut.

4. Anak yang lahir dalam tenggang waktu 300 hari setelah ayahnya meninggal dunia dari perkawinan yang sah, dan ayahnya itu seorang WNI.

5. Anak yang lahir di luar perkawinan yang sah dari ibu WNI

6. Anak yang lahir di luar perkawinan yang sah dari ibu WNA yang diakui oleh seorang ayah WNI sebagai anaknya dan pengakuan itu dilakukan sebelum anak tersebut berusia 18 tahun atau belum kawin.

7. Anak yang lahir di wilayah Negara Republik Indonesia yang pada waktu lahir tidak jelas status kewarganegaraan ayah dan ibunya,

8. Anak yang baru lahir yang ditemukan di wilayah Negara Republik Indonesia selama ayah dan ibunya tidak diketahui.

9. Anak yang lahir di wilayah Negara Republik Indonesia apabila ayah dan ibunya tidak memiliki kewarganegaraan atau tidak diketahui keberadaannya..

10. Anak yang dilahirkan di luar wilayah Republik Indonesia dari ayah dan ibu WNI, yang karena ketentuan dari negar tempat anak tersebut dilahirkan memberikan kewarganegaraan kepada anak yang bersangkutan.

11. Anak dari seorang ayah atau ibu yang telah dikabulkan permohonan kewarganegarannya, kemudian ayah atau ibunya meninggal dunia sebelum mengucapkan sumpah atau menyatakan janji setia.

Selanjutnya dalam UU Nomor 12 Tahun 2006 tersebut diakui pula sebagai WNI adalah :

1. Anak WNI yang lahir di luar perkawinan yang sah, belum berusia 18 tahun dan belum kawin, diakui secara sah oleh ayahnya yang berkewarganegaraan asing.

2. Anak WNI yang belum berusia lima tahun, yang diangkat secara sah sebagai anak oleh WNA berdasarkan penetapan pengadilan.

3. Anak yang belum berusia 18 tahun atau belum kawin, berada dan bertempat tinggal di wilayah RI, yang ayah atau ibunya memperoleh kewarganegaraan Indonesia.

4. Anak WNA yang belum berusia limatahun yang diangkat anak secara sah menurut penetapan pengadilan sebagai anak oleh WNI. 
5. Anak yang belum berusia 18 tahun atau belum kawin, berada dan bertempat tinggal di wilayah Republik Indonesia, yang ayah atau ibunya memperoleh kewarganegaraan Indonesia.

6. Anak warga Negara asing yang belum berusia lima tahun yang diangkat anak secara sah menurut penetapan pengadilan sebagai anak oleh warga Negara Indonesia.

Perwujudan dalam memperoleh keamanan terjamin dalam focus penelitian ini, Kebijakan hukum dilakukan adanya peraturan-peraturan yang dibuat oleh Pemerintah yang bertujuan memberikan perlindungan hukum. Adapun peraturan - peraturan dimaksud adalah Kitab Undang Undang Hukum Pidana (KUHP), Undang Undang Nomor 4 Tahun 1979 tentang Kesejahteraan Anak, Undang Undang Nomor 39 Tentang Hak Asasi Manusia, Undang Undang Nomor 23 Tahun 2004 Tentang Penghapusan Kekerasan Dalam Rumah Tangga, Undang Undang Nomor 35 Tahun 2014 tentang Perubahan Atas Undang Undang 23 Tahun 2002 Tentang Perlindungan Anak.

Perlindungan Hukum Terhadap Anak Korban Penelantaran Oleh Orang Tua di dalam KUHP, terdapat lima Pasal yaitu pasal 304, 305, 306, 307, 309. kedudukan anak dalam hukum pidana telah dijelaskan KUHP diletakkan dalam pengertian seorang anak yang belum dewasa, sebagai orang yang mempunyai hak-hak khusus dan perlu mendapatkan perlindungan menurut ketentuan hukum yang berlaku. Pengertian anak dalam hukum pidana menimbulkan aspek hukum positif terhadap proses normalisasi anak dari perilaku menyimpang untuk membentuk kepribadian dan tanggung jawab yang pada akhirnya anak tersebut berhak atas kesejahteraan yang layak. Pengertian anak dalam KUHP dapat kita ambil contoh dalam Pasal 287 KUHP, dalam Pasal disebutkan bahwa anak di bawah umur adalah apabila anak tersebut belum mencapai usia 15 (lima belas) tahun. Sebagaimana diketahui bahwa penelantaran anak merupakan penasehat hukum atau pengurus atas penetapan pengadilan, hak menjadi wali, wali pengawas, pengampu atau pengampu pengawas, atas orang yang bukan anak sendiri; maka sanksi bagi pelaku penelantaran anak orang tua sebagai berikut

Pasal 304

Barang siapa dengan sengaja menempatkan atau membiarkan seorang dalam keadaan sengsara, padahal menurut hukum yang berlaku baginya atau karena persetujuan dia wajib memberi kehidupan, perawatan atau pemeliharaan kepada 
orang itu, diancam dengan pidana penjara paling lama dua tahun delapan bulan atau pidana denda paling banyak empat ribu lima ratus rupiah.

Pasal 305

Barang siapa menempatkan anak yang umurnya belum tujuh tahun untuk ditemukan atau meninggalkan anak itu dengan maksud untuk melepaskan diri daripadanya, diancam dengan pidana penjara paling lama lima tahun enam bulan.

Pasal 306

(1) Jika salah satu perbuatan berdasarkan pasal 304 dan 305 mengakibatkan lukaluka berat, yang bersalah diancam dengan pidana penjara paling lama tujuh tahun enam bulan.

(2) Jika mengakibatkan kematian pidana penjara paling lama sembilan tahun.

Pasal 307

Jika yang melakukan kejahatan berdasarkan pasal 305 adalah bapak atau ibu dari anak itu, maka pidana yang ditentukan dalam pasal 305 dan 306 dapat ditambah dengan sepertiga.

Pasal 309

Dalam hal pemidanaan berdasarkan salah satu kejahatan dalam pasal 304 - 308, maka hak-hak tersebut dalam pasal 35 No. 4 dapat dicabut.

adapun maksud dari pasal 35 No. 4 adalah pencabutan hak asuh, wali, pengawas orang tua terhadap anak berdasarkan penetapan pengadilan.

Sementara yang dimaksud dengan "luka berat" dalam Pasal 306, dapat merujcik pada ketentuan Pasal 90 KUHP, yang menggariskan bahwa : Luka berat berarti:

1. Jatuh sakit atau mendapat luka yang tidak memberi harapan akan sembuh sama sekali, atau yang menimbulkan bahaya maut;

2. Tidak mampu terus-menerus untuk menijalankan tugas jabatan atau pekeijaan pencarian;

3. Kehilangan salah satu pancaindera;

4. Mendapat cacat berat;

5. Menderita sakit lumpuh;

6. Terganggunya daya pikir selama empat minggu lebih; 
Perlindungan Hukum Terhadap Anak Korban Penelantaran Oleh Orang Tua menurut Undang Undang Nomor 4 Tahun 1979 tentang Kesejahteraan Anak, dimana didalam Undang Undang ini diatur hak-hak anak, tugas dan tanggung jawab sebagai orang tua terhadap anak-anak mereka dan peranan Pemerintah mengadakan pengarahan, bimbingan, bantuan, dan pengawasan terhadap usaha kesejahteraan anak yang dilakukan oleh masyarakat, dengan penjelasan sebagai berikut:

Pasal 2

(1) Anak berhak atas kesejahteraan, perawatan, asuhan dan bimbingan berdasarkan kasih sayang baik dalam keluarganya maupun di dalam asuhan khusus untuk tumbuh dan berkembang dengan wajar.

(2) Anak berhak atas pelayanan untuk mengembangkan kemampuan dan kehidupan sosialnya, sesuai dengan kebudayaan dan kepribadian bangsa, untuk menjadi warganegara yang baik dan berguna.

(3) Anak berhak atas pemeliharaan dan perlidungan, baik semasa dalam kandungan maupun sesudah dilahirkan.

(4) Anak berhak atas perlindungan terhadap lingkungan hidup yang dapat membahayakan atau menghambat pertumbuhan dan perkembangannya dengan wajar.

Pasal 3

Dalam keadaan yang membahayakan, anaklah yang pertama-tama berhak mendapat pertolongan, bantuan, dan perlindungan.

Pasal 9

Orang tua adalah yang pertama-tama bertanggungjawab atas terwujudnya kesejahteraan anak baik secara rohani, jasmani maupun sosial.

Pasal 10

(1) Orang tua yang terbukti melalaikan tanggungjawabnya sebagaimana termaksud dalam Pasal 9, sehingga mengakibatkan timbulnya hambatan dalam pertumbuhan dan perkembangan anak, dapat dicabut kuasa asuhnya sebagai orang tua terhadap anaknya. Dalam hal itu ditunjuk orang atau badan sebagai wali.

(2) Pencabutan kuasa asuh dalam ayat (1) tidak menghapuskan kewajiban orang tua yang bersangkutan untuk membiayai, sesuai dengan kemampuannya, 
penghidupan, pemeliharaan, dan pendidikan anaknya. (3) Pencabutan dan pengembalian kuasa asuh orang tua ditetapkan dengan keputusan hakim.

Pasal 11

(1) Usaha kesejahteraan anak terdiri atas usaha pembinaan, pengembangan, pencegahan, dan rehabilitasi.

(2) Usaha kesejahteraan anak dilakukan oleh Pemerintah dan atau masyarakat.

(3) Usaha kesejahteraan anak yang dilakukan oleh Pemerintah dan atau masyarakat dilaksanakan baik di dalam maupun di luar Panti.

(4) Pemerintah mengadakan pengarahan, bimbingan, bantuan, dan pengawasan terhadap usaha kesejahteraan anak yang dilakukan oleh masyarakat.

Perlindungan Hukum Terhadap Anak Korban Penelantaran Oleh Orang Tua Menurut Undang Undang Nomor 39 Tentang Hak Asasi Manusia, dimana Anak adalah setiap manusia yang berusia di bawah 18 (delapan belas) tahun dan belum menikah, termasuk anak yang masih dalam kandungan apabila hal tersebut adalah demi kepentingannya (Pasal 1 Angka 5) yang memiliki asas-asas dasar sebagai hak asasi manusia yang diakui dan dijunjung oleh Negara Republik Indonesia sebagai hak yang secara kodrati melekat pada dan tidak terpisahkan dari manusia, yang harus dilindungi, dihormati, dan ditegakkan demi peringatan martabat kemanusiaan, kesejahteraan, kebahagiaan, dan kecerdasan serta keadilan (Pasal 2). Dalam rangka penegakan hak asasi manusia, perbedaan dan kebutuhan dalam masyarakat hukum adat harus diperhatikan dan dilindungi oleh hukum, masyrarakat, dan pemerintah (Pasal 6 ayat (1)) menjadi tanggung jawab pemerintah (Pasal 8).

Perlindungan Hukum Terhadap Anak Korban Penelantaran Oleh Orang Tua Menurut Undang Undang Nomor 23 Tahun 2004 Tentang Penghapusan Kekerasan Dalam Rumah Tangga. Dimana anak merupakan bagian dari lingkup keluarga dan dilarang melakukan kekerasan terhadap anak dan pengaturan sanksi pidana bagi pelaku yang melakukan kekerasan terhadap anak, diketahui bahwa penelantaran anak oleh orang tua merupakan wujud kekerasan yang dapat berdampak fisik maupun psikis, menyatakan bahwa :

Pasal 2

(1) Lingkup rumah tangga dalam Undang-Undang ini meliputi:

a. suami, isteri, dan anak; 


\section{Pasal 5}

Setiap orang dilarang melakukan kekerasan dalam rumah tangga terhadap orang dalam lingkup rumah tangganya, dengan cara:
a. kekerasan fisik;
b. kekerasan psikis;
c. kekerasan seksual; atau
d. penelantaran rumah tangga.

\section{Pasal 6}

Kekerasan fisik sebagaimana dimaksud dalam Pasal 5 huruf a adalah perbuatan yang mengakibatkan rasa sakit, jatuh sakit,atau luka berat.

\section{Pasal 7}

Kekerasan psikis sebagaimana dimaksud dalam Pasal 5 huruf $\mathrm{b}$ adalah perbuatan yang mengakibatkan ketakutan, hilangnya rasa percaya diri, hilangnya kemampuan untuk bertindak, rasa tidak berdaya, dan/atau penderitaan psikis berat pada seseorang

Pasal 15

Setiap orang yang mendengar, melihat, atau mengetahui terjadinya kekerasan dalam rumah tangga wajib melakukan upaya-upaya sesuai dengan batas kemampuannya untuk:

a. mencegah berlangsungnya tindak pidana;

b. memberikan perlindungan kepada korban;

c. memberikan pertolongan darurat; dan

d. membantu proses pengajuan permohonan penetapan perlindungan.

Pasal 27

Dalam hal korban adalah seorang anak, laporan dapat dilakukan oleh orang tua, wali, pengasuh, atau anak yang bersangkutan yang dilaksanakan sesuai dengan ketentuan peraturan perundang undangan yang berlaku.

Pasal 44

(1) Setiap orang yang melakukan perbuatan kekerasan fisik dalam lingkup rumah tangga sebagaimana dimaksud dalam Pasal 5 huruf a dipidana dengan pidana penjara paling lama 5 (lima) tahun atau denda paling banyak Rp15.000.000,00 (lima belas juta rupiah). 
(2) Dalam hal perbuatan sebagaimana dimaksud pada ayat (1) mengakibatkan korban mendapat jatuh sakit atau luka berat, dipidana dengan pidana penjara paling lama 10 (sepuluh) tahun atau denda paling banyak Rp30.000.000,00 (tiga puluh juta rupiah).

(3) Dalam hal perbuatan sebagaimana dimaksud pada ayat (2) mengakibatkan matinya korban, dipidana dengan pidana penjara paling lama 15 (lima belas) tahun atau denda paling banyak Rp45.000.000,00 (empat puluh lima juta rupiah).

(4) Dalam hal perbuatan sebagaimana dimaksud pada ayat (1) dilakukan oleh suami terhadap isteri atau sebaliknya yang tidak menimbulkan penyakit atau halangan untuk menjalankan pekerjaan jabatan atau mata pencaharian atau kegiatan seharihari, dipidana dengan pidana penjara paling lama 4 (empat) bulan atau denda paling banyak Rp5.000.000,00 (lima juta rupiah).

Pasal 45

(1) Setiap orang yang melakukan perbuatan kekerasan psikis dalam lingkup rumah tangga sebagaimana dimaksud pada Pasal 5 huruf $\mathrm{b}$ dipidana dengan pidana penjara paling lama 3 (tiga) tahun atau denda paling banyak Rp9.000.000,00 (sembilan juta rupiah).

(2) Dalam hal perbuatan sebagaimana dimaksud pada ayat (1)dilakukan oleh suami terhadap isteri atau sebaliknya yang tidak menimbulkan penyakit atau halangan untuk menjalankan pekerjaan jabatan atau mata pencaharian atau kegiatan seharihari, dipidana dengan pidana penjara paling lama 4 (empat) bulan atau denda paling banyak Rp3.000.000,00 (tiga juta rupiah).

Adanya penelantaran anak serta pengabaian hak-hak dan kewajiban pihak yang menjadi korban merupakan suatu indikator adanya ketidakseimbangan dalam tanggung jawab anggota masyarakat semacam ini, manusia tidak dilindungi secara baik. Penelantaran anak dalam konteks hukum Indonesia sangatlah tidak dibenarkan, karena bertentangan dengan aturan hukum lainnya yaitu Undang Undang Nomor 35 Tahun 2014 tentang Perubahan Atas Undang Undang 23 Tahun 2002 Tentang Perlindungan Anak.

Undang Undang Nomor 35 Tahun 2014 tentang Perubahan Atas Undang Undang 23 Tahun 2002 Tentang Perlindungan Anak mulai berlaku semenjak 17 Oktober 2014 dengan dasar pertimbangan anak sebagai tunas, potensi, dan generasi muda penerus citacita perjuangan bangsa memiliki peran strategis, ciri, dan sifat khusus sehingga wajib 
dilindungi dari segala bentuk perlakuan tidak manusiawi yang mengakibatkan terjadinya pelanggaran hak asasi manusia; dan dalam rangka meningkatkan perlindungan terhadap anak perlu dilakukan penyesuaian terhadap beberapa ketentuan dalam Undang-Undang Nomor 23 Tahun 2002 tentang Perlindungan Anak.

Berkaitan dengan penelantaran anak didalam Undang Undang Nomor 35 Tahun 2014 termasuk kedalam tindakan kekerasan terhadap anak, secara jelas dinyatakan Pasal 1 Angka 15a : "Kekerasan adalah setiap perbuatan terhadap Anak yang berakibat timbulnya kesengsaraan atau penderitaan secara fisik, psikis, seksual, dan/atau penelantaran, termasuk ancaman untuk melakukan perbuatan, pemaksaan, atau perampasan kemerdekaan secara melawan hukum.". sehingga anak berhak memperoleh perlindungan dari kekerasan yang dialami (Pasal 15) dan menjadi tanggung jawab Pemerintah, Pemerintah Daerah, Masyarakat, Keluarga, dan Orang Tua, menyatakan :

Pasal 20

Negara, Pemerintah, Pemerintah Daerah, Masyarakat, Keluarga, dan Orang Tua atau Wali berkewajiban dan bertanggung jawab terhadap penyelenggaraan Perlindungan Anak

Orang tua yang menjadi pelaku penelantaran terhadap anaknya didalam Undang Undang Nomor 35 Tahun 2014 secara tegas dilarang keras, sebagai berikut :

Pasal 76B

Setiap Orang dilarang menempatkan, membiarkan, melibatkan, menyuruh melibatkan Anak dalam situasi perlakuan salah dan penelantaran.

Pasal 76C

Setiap Orang dilarang menempatkan, membiarkan, melakukan, menyuruh melakukan, atau turut serta melakukan Kekerasan terhadap Anak.

Selanjutnya di dalam Undang Undang Nomor 35 Tahun 2014, sanksi hukuman pelaku penelanataran anak telah diatur sebagai berikut :

Pasal 77B

Setiap Orang yang melanggar ketentuan sebagaimana dimaksud dalam Pasal 76B, dipidana dengan pidana penjara paling lama 5 (lima) tahun dan/atau denda paling banyak Rp100.000.000,00 (seratus juta rupiah).

Pasal 80 
(1) Setiap Orang yang melanggar ketentuan sebagaimana dimaksud dalam Pasal 76C, dipidana dengan pidana penjara paling lama 3 (tiga) tahun 6 (enam) bulan dan/atau denda paling banyak Rp72.000.000,00 (tujuh puluh dua juta rupiah).

(2) Dalam hal Anak sebagaimana dimaksud pada ayat (1) luka berat, maka pelaku dipidana dengan pidana penjara paling lama 5 (lima) tahun dan/atau denda paling banyak Rp100.000.000,00 (seratus juta rupiah).

(3) Dalam hal Anak sebagaimana dimaksud pada ayat (2) mati, maka pelaku dipidana dengan pidana penjara paling lama 15 (lima belas) tahun dan/atau denda paling banyak Rp3.000.000.000,00 (tiga miliar rupiah).

2. Analisa Perlindungan Hukum Terhadap Anak Korban Penelantaran Oleh Orang Tua Di Indonesia

Negara Indonesia telah memiliki kebijakan hukum dalam bentuk peraturanperaturan memberikan perlindungan hukum terhadap anak korban penelantaran oleh orang tua dan memberikan sanksi hukuman bagi orang tua sebagai pelaku penelantaran. Namun dalam penegakan hukum terhadap kasus penelantaran anak oleh orang tua belum optimal memberikan perlindungan hukum terhada anak sebagai korban. Hal ini didasarkan pada laporan jumlah penelantaran anak oleh orang tua makin hari terus meningkat sebagaimana data Kementerian Sosial pada tahun 2014 berjumlah 5,900 anak dan mengalami kenaikan sebesar $4,8 \%$ dari tahun sebelumnya

Peningkatan jumlah penelantaran anak oleh orang tua disebabkan oleh faktor internal dan eksternal. Faktor Internal, berupa :

1. Faktor ekonomi, penghasilan yang diperoleh oleh orang tua dalam mencukupi kebutuhan keluarga dan anak-anak menuntut orang tua menelantarkan dan sasaran kemarahan kepada anaknya.

2. Kekerasan yang dilakukan kepada istri atau suami membawa dampak kepada anak yang juga menjadi sasaran kemarahan sehingga pada saat menjadi Orang tua yang "berbakat" menganiaya anaknya

3. Adanya peranan ayah dan ibu yang tidak berjalan sebagaimana mestinya dimana ayah sebagai pemimpin keluarga, dan ibu sebagai yang membimbing dan menyayangi atau orangtua tunggal lebih memungkinkan melakukan tindakan kekerasan fisik terhadap anak dibandingkan dengan orangtua utuh. Karena keluarga dengan orangtua tunggal biasanya berpendapatan lebih kecil dibandingkan keluarga lain, sehingga hal tersebut dapat dikatakan sebagai 
penyebab meningkatnya tindak kekerasan terhadap anak. Keluarga - keluarga yang sering bertengkar secara kronis atau istri yang diperlakukan salah mempunyai tingkat tindakan kekerasan terhadap anak yang lebih tinggi dibandingkan dengan keluarga yang tanpa masalah.

4. Adanya Stres yang ditimbulkan oleh berbagai kondisi sosial meningkatkan resiko kekerasan terhadap anak dalam keluarga. Kondisi - kondisi sosial ini mencakup : pengangguran, penyakit, kondisi perumahan buruk, ukuran keluarga besar dari rata - rata, kelahiran bayi baru, adanya orang cacat dirumah dan kematian seorang anggota keluarga.

5. Pandangan keliru tentang posisi anak dalam keluarga, orang tua menganggap bahwa anak adalah sosok yang lemah, tidak tahu apa-apa sehingga berdampak kepada pola asuh yang salah diberikan oleh orang tua.

6. Faktor pendidikan, tingkat pendidikan orang tua yang rendah sehingga berdampak terhadp pola asush terhadap anak-anaknya seperti sewenangwenang, tidak mengetahui bahwa anak adalah penerus bangsa yang dilindungi oleh pemerintah sebagaimana diatur di dalam Undang Undang.

Sedangkan factor eksternal terjadinya perbuatan penelantaran anak oleh orang tua adalah Kelakuan anak itu sendiri, seperti anak malas, susah untuk ditegur oleh orang tua didukung juga oleh orang tua yang telah letih bekerja seharian sehingga timbul kekerasan yang dianggap orang tua sebagai pola asuh, hukuman dari orang tua seperti tidur diluar kamar, tidak diberi uang jajan yang terus dilakukan oleh anak sehingga timbul pengusiran oleh orang tua dalam rangka mendidik, anak menderita gangguan perkembangan, menderita penyakit kronis, disebabkan ketergangtungan anak pada lingkungannya, anak mengalami cacat tubuh, retardasi mental, gangguan tingkah laku, autisme dan anak yang melakukan perilaku menyimpang.

Tindakan penelantaran orang tua terhadap anaknya membawa dampak bagi terganggunya perkembangan anak dimana kurangnya perhatian dan kasih sayang orang tua terhadap anak menyebabkan anak memiliki rasa tidak aman, gagal mengembangkan perilaku akrab, mengalami masalah penyesuaian diri pada masa yang akan datang dan menimbulkan dampak psikis dimana anak tidak tahu harus mengadu terhadap permasalahan-permasalahan yang dihadapi

Kasus Penelantaran Anak oleh Orang Tua sebagai fokus kajian penelitian dalam kenyataan penegakan hukumnya tidak ada satupun yang diproses sampai ke tahap 
peradilan, hal ini merujuk pada Teori yang dikemukakan oleh Harkristuti Harkrisnowo memiliki kelemahan-kelemahan, maka Kajian ketiga aspek yang dikemukakan diperoleh sebagai berikut :

\section{Aspek Struktur}

Aspek ini meliputi pihak-pihak yang membentuk maupun menerapkan hukum atau law enforcement. Bagian-bagian itu law enforcement adalah aparatur penegak hukum yang mampu memberikan kepastian, keadilan, dan kemanfaat hukum secara proporsional. Aparatur penegak hukum menyangkup pengertian mengenai institusi penegak hukum dan aparat (orangnya) penegak hukum, sedangkan aparat penegak hukum dalam srti sempit dimulai dari kepolisian, kejaksaan, kehakiman, penasehat hukum dan petugas sipir lembaga pemasyarakatan. Setiap aparat dan aparatur diberikan kewenangan dalam melaksanakan tugasnya masing-masing, yang meliputi kegiatan penerimaan laporan, penyelidikan, penyidikan, penuntutan, pembuktian, penjatuhan vonis dan pemberian sanksi, serta upaya pembinaan kembali terpidana.

Sistem peradilan pidana haruslah merupakan suatu kesatuan terpadu dari usahausaha untuk menanggulangi kejahatan yang sesungguhnya terjadi dalam masyarakat. Apabila kita hanya memakai sebagian ukuran statistik kriminalitas., maka keberhasilan sistem peradilan pidana akan dinilai berdasarkan jumlah kejahatan yang sampai alat penegak hukum. Beberapa banyak yang dapat diselesaikan kepolisian, kemudian diajukan oleh kejaksaan ke pengadilan dan dalam pemeriksaan di pengadilan dinyatakan bersalah dan dihukum. Sebenarnya apa yang diketahui dan diselesaikan melalui system peradilan pidana hanya puncaknya saja dari gunung es. Masih banyak yang tidak terlihat, tidak dilaporkan (mungkin pula tidak diketahui misalnya dalam hal "kejahatan dimana korbannya tidak dapat ditentukan atau "crimes without victims") dan karena itu tidak dapat diselesaikan. Keadaan seperti ini tidak dapat dipersalahkan sepenuhnya kepada system peradilan pidana. Karena tugas system ini terutama menyelesaikan kasus-kasus yang sampai padanya.

Secara sosiologis, setiap aparat penegak hukum tersebut mempunyai kedudukan (status) dan peranan (role). Kedudukan (sosial) merupakan posisi tertentu di dalam struktur kemasyarakatan. Kedudukan tersebut merupakan peranan atau role, oleh karena itu seseorang yang mempunyai kedudukan tertentu, lazimnya mempunyai peranan. Suatu hak merupakan wewenang untukberbuat dan tidak berbuat, sedangka kewajiban adalah beban atau tugas. 
Suatu peranan tertentu dapat dijabarkan dalam unsure-unsur sebagai berikut :

1. Peranan yang ideal / ideal role

2. Peranan yang seharusnya / expected role

3. Peranan yang dianggap oleh diri sendiri / perceived role, dan

4. Peranan yang sebenarnya dilakukan / actual role. Penegak gukum dalam menjalankan perannya tidak dapat berbuat sesuka hati mereka juga harus memperhatikan etika yang berlaku dalam lingkup profesinya, etika memperhatikan atau mempertimbangkan tingkah laku manusia dalam pengambilan keputusan moral. Dalam profesi penegak hukumm sendiri mereka telah memiliki kode etik yang diatur tersendiri, tapi dalam prakteknya kode etik yang telah diterapkan dan di sepakati itu masih banya di langgar oleh para penegak hukum. Akibat perbuatan - perbuatan para penegak hukum yang tidak memiliki integritas bahkan dapat dikatakan tidak beretika dalam menjalankan profesinya sehingga mengakibatkan lambatnya pembangunan hukum yang diharapkan oleh bangsa ini, bahkan menimbulkan pikiran - pikiran negative dan mengurangi kepercayaan masyarakat terhadap kinerja penegak hukum.

Dalam pelaksanaannya penegak hukum oleh penegak hukum di atas dijumpai beberapa halangan yang disebabkan oleh penegak hukum itu sendiri dalam kasus penelantaran anak oleh orang tua, halangan-halangan tersebut antara lain :

1. Keterbatasan kemampuan untuk menempatkan diri dalam peranan pihak lain dengan siapa dia berinteraksi. Maksudnya adalah keterbatasan kemampuan penegak hukum untuk memancing keterbukaan anak yang menjadi korban penelantaran oleh orang tua sebagai saksi untuk menceritakan kejadian-kejadian yang dialaminya.

2. Tingkat aspirasi yang relative belum tinggi.

3. Kegairahan yang sangat terbatas untuk memikirkan masa depan sehinga sulit sekali untuk membuat suatu proyeksi.

4. Belum adanya kemampuan untuk menunda pemuasan suatu kebutuhan tertentu terutama kebutuhan material.

5. Kurangnya daya inovatif yang sebenarnya merupakan pasangan konservatisme.

hambatan maupun halangan penegak hukum dalam melakukan penegakan hukum tersebut dapat diatasi dengan cara mendidik, membiasakan diri untuk mempunyai 
sikap-sikap antara lain : sikap terbuka senantiasa siap menerima perubahan melalui pelatihan-pelatihan berbasic psikologi dan mental anak, peka terhadap masalah yang terjadi dialami oleh anak yang menjadi korban, senantiasa mempunyai informasi yang lengkap yaitu menyangkut integritas penegak hukum di dalam penyelidikan dan penyidikan secara terperinci terhadap kasus penelantaran anak oleh orang tua, orientasi ke masa kini dan masa depan, menyadari potensi yang dapat di kembangkan, berpegang pada suatu perencanaan, percaya pada kemampuan iptek, menyadari dan menghormati hak dan kewajiban, berpegang teguh pada keputusan yang diambil atas dasar penalaran dan perhitungan yang mantab.

\section{Aspek substansi}

Setiap masyarakat memiliki hukum sebagai normative dalam hubungan antar warga masyarakat, hal ini bertujuan agar hubungan masyarakat berlangsung lestari dan mencapai tujuan bersama. Sedangkan hukum bersifat mengatur dan memaksa melalui sanksi-sanksi yang dijatuhkan terhadap para pelanggar hukum antara lain berupa hukuman pidana.

Hukum pidana sendiri adalah bagian daripada keseluruhan hukum yang berlaku di suatu negara, yang mengadakan dasar-dasar dan aturan-aturan untuk :

1. Menentukan perbuatan-perbuatan mana yang tidak boleh dilakukan, yang dilarang dengan disertai ancaman atau sanksi yang berupa pidana tertentu bagi siapa yang melarang perbuatan penelantaran anak oleh orang tua.

2. Menentukan kapan dan dalam hal-hal apa kepada mereka yang telah melanggar larangan-larangan itu dapat dikenakan atau dijatuhi pidana sebagai mana yang diancamankan dilain sisi negara memberikan tanggung jawab kepada orang tua untuk memberikan mengasuh, memlihara, mendidik, dan melindungi anak : menumbuhkembangkan anak sesuai dengan kemampuan bakat dan minatnya serta memberikan pendidikan karakter dan penanaman nilai budi pekerti pada anak dan orang tua menunjukkan sikap tidak peduli terhadap anak (penelantaran) sebagai pola pendidikan agar anak mandiri.

3. Menentukan dengan cara bagaimana pengenaan pidana itu dapat dilaksanakan apabila ada orang yang disangka telah melanggar larangan tersebut.

Akibatnya didalam penerapan hukum pidana atau undang-undang oleh penegak hukum pada kenyataannya tidak berjalan seperti fungsi dan tyjuan hukum pidana yang 
dimaksud, hal ini merupakan gangguan penegakan hukum yang berasal dari hukum pidana dan atau undang-undang yang mungkin disebabkan karena :

1. Belum adanya peraturan pelaksanaan yang sangat dibutuhkan untuk menerapkan undang-undang, dan

2. Ketidak jelasan arti kata-kata didalam undang-undang yang mengakibatkan kesipang siuran di dalam penafsiran dan penerapannya.

Untuk menghindari atau mencegah permaslaahan penegakan hukum yang berasal dari hukum pidan adan atau undang-undang seperti tersebut diatas, maka perlu diperhatikan dasar kontruksi hukum pembuatan hukum pidana.

\section{Aspek Kultur}

Aspek kultur dengan masyarakat bertujuan untuk mencapai kedamaian didalam masyarakat. Masyarakat juga mempounyai kecenderungan yang besar untuk mengartikan hukum dan bahkan mengidentifikasi dengan petugas (dalam hal ini adalah penegak hukum adalah sebagai pribadi).

Salah satu akibatnya adalah bahwa baik buruknya hukum senantiasa dikaitkan dengan pola perilaku penegak hukum itu sendiri yang merupakan pendapatnya sebagai cerminan dari hukum sebagai struktur dan proses. Keadaan tersebut juga dapat memberikan pengaruh baik yakni bahwa penegak hukum akan merasa bahwa prilakunya senantiasa mendapat perhatian dari masyarakat.

Permasalahan lain yang timbul sebagai akibat anggapan masyarakat adalah mengenai penerapan undang-undang yang ada / berlaku. Jika penegak hukum menyadari dirinya dianggap hukum oleh masyarakat, maka kemungkinan penafsiran mengenai pengertian perundang-undangan bisa terlalu luas atau bahkan terlalu sempit. Selain itu mungkin timbul kebiasaan untuk kurang menelaah bahwa perundang-undangan kadangkala tertinggal dengan perkembangan di dalam masyarakat. Anggapan-anggapan masyarakat tersebut harus mengalami perubahan dalam kadar tertentu. Perubahan tersebut dapat dilakukan melalui penerangan atau penyuluhan hukum yang berkesinambungan dan senantiasa dievaluasi hasil-hasilnya untuk kemudian dikembangkan lagi. Kegiatankegiatan tersebut nantinya kita dapat menempatkan hukum pada kedudukan dan peranan yang semestinya.

Penelantaran anak oleh orang tua dalam penegakan hukum mengalami kendalakendala yaitu : 
a. orang tua sendiri yang merupakan pelaku penelantaran, sehingga kebanyakan keluarga yang tidak melaporkan kasus ini. Karena apabila kasus ini tersebar, maka hanya akan menjadii aib bagi keluarga.

b. Sulitnya mendapat keterangan yang sebenar-benarnya dari korban anak, apabila ada orang tua di sisinya.

c. Adanya intervensi dari pihak keluarga yang mengintimidasi si Anak sehingga kasus ini seperti ditutup tutupi.

d. Kesulitan dalam Reintegrasi, hal ini dikarenakan orang tua tidak mau menerima anak itu kembali di dalam keluarga. Hal ini disebabkan kekecewaan orang tua yang merasa anaknya telah mencemari nama baik keluarga.

Upaya untuk mengatasi hambatan dalam melaksanakan perlindungan hukum kepada anak korban penelantaran oleh orang tua yaitu secara preventif dan represif. Adapun upaya yang dilakukan dalam mencegah terjadinya penelantaran anak oleh orang tua , berupa:

1. Pengaturan dalam perspektif normatif yakni Peraturan Perundang-Undangan, ada beberapa hal yang harus diperhatikan seperti sanksi pidana, dalam pemberian sanksi pidana terhadap pelaku sebaiknya diberikan hukuman seberat-beratnya. Pemberian sanksi berat tersebut harus diperhatikan pada motif pelaku, tujuan pelaku melakukan tindak pidana, cara pelaku melakukan tindak pidana dan motif korban. Meningkatkan kerjasama sesama Lembaga penyantun korban dan berkoordinasi dengan pihak kepolisian harus dilakukan, agar kepolisian segera meminta bantuan lembaga ini ketika mendapat laporan terjadinya tindak kekerasan terhadap anak. Lembaga ini perlu didukung setidaknya oleh pekerja sosial, psikolog, ahli hukum dan dokter. Dalam kondisi daerah yang tidak memungkinkan, harus diupayakan untuk menempatkan orang-orang dengan kualifikasi yang paling mendekati para profesional di atas, dengan maksud agar lembaga ini dapat mencapai tujuan yang diinginkan dengan baik. Pendanaan untuk lembaga ini harus dimulai dari pemerintah sendiri, baik pusat maupun daerah, dan tentunya dapat melibatkan masyarakat setempat baik secara individu maupun kelompok.

Sedangkan Secara Represif diperlukan perlindungan hukum berupa:

1. Sosialisasi penguatan keluarga ini dapat dilakukan dengan berbagai cara diantaranya Jalin kokmunikasi yang baik di rumah. Usahakan agar orang ua dapat mengetahui halhal apa saja yang telah dilakukan anaknya di luar rumah. Komunikasi ini juga dapat 
mempererat kedekatan orang tua kepada anak, dan sebalikna sehingga anak lebih jujur kepada orang tua dan orang tua dapat menjadi sahabat bagi si anak dan menjadi teman curhat bagi sang anak.

Menitikberatkan penyuluhan bahwa peranan orang tua peranan orang tua terhadap anaknya dalam pendidikan yaitu meliputi : Kebutuhan akan rasa kasih saying; Kebutuhan akan rasa aman, Kebutuhan akan harga diri, Kebutuhan akan rasa kebebasan, Kebutuhan akan rasa sukses, Kebutuhan akan mengenal.

2. pemberian restitusi dan kompensasi bertujuan mengembalikan kerugian yang dialami oleh korban baik fisik maupun psikis, serta penggantian atas biaya yang dikeluarkan sebagai akibat viktimisasi tersebut. Mengenai hak ini diatur dalam Pasal 98 ayat (1) KUHAP, yaitu: Jika suatu perbuatan yang menjadi dasar dakwaan di dalam suatu pemeriksaan perkara pidana oleh Pengadilan Negeri menimbulkan kerugian bagi orang lain, maka Hakim Ketua Sidang atas permintaan orang itu dapat menetapkan untuk menggabungkan perkara gugatan ganti kerugian kepada perkara pidana itu.Ketentuan yang ada dalam Pasal 98 KUHAP tersebut, tentang kemungkinan korban mendapat ganti kerugian sangatlah kurang, terutama karena ganti kerugian yang diperkenankan adalah yang berkenaan dengan penggantian biaya yang telah dikeluarkan oleh pihak yang dirugikan (korban).

3. Konseling diberikan kepada anak sebagai korban penelantaran oleh orang tua yang mengalami trauma berupa rehabilitasi yang bertujuan untuk mengembalikan kondisi psikis korban semula.

4. Pelayanan / bantuan medis, diberikan kepada korban anak yang menderita secara medis dan sosial. rehabilitasi medis tersebut adalah proses kegiatan pengobatan secara terpadu dengan memulihkan kondisi fisik anak, anak korban dan atau anak saksi. Kemudian yang dimaksud dengan rehabilitasi sosial adalah proses kegiatan pemulihan secara terpadu, baik fisik, mental maupun sosial, agar anak korban, dan atau anak saksi dapat kembali melaksanakan fungsi sosial dalam kehidupan di masyarakat.

5. perlindungan yang diberikan oleh masyarakat. Masyarakat mempunyai andil besar dalam membantu memberikan perlindungan kepada korban. Hal ini dengan dapat ditunjukkan dengan selalu menghibur korban (anak), tidak mengungkit-ungkit dengan menanyakan peristiwa yang telah dialaminya, memberi dorongan dan motivasi bahwa korban tidak boleh terlalu larut dengan masalah yang dihadapinya, Sedangkan 
berkaitan dengan peran masyarakat oleh media massa harus dilakukan dengan bijaksana demi perlindungan anak

6. Perlindungan anak yang bersifat non-yuridis dapat berupa, pengadaan kondisi sosial dan lingkungan yang kondusif bagi pertumbuhan anak, kemudian upaya peningkatan kesehatan dan gizi anak-anak, serta peningkatan kualitas pendidikan melalui berbagai program bea siswa dan pengadaan fasilitas pendidikan yang lebih lengkap dan canggih.

Berdasarkan uraian yang telah dikemukakan penulis diperlukan koordinasi antara Pemerintah, Orang Tua, Guru dan masyarakat dalam memberikan perlindungan terhadap anak sehingga dapat meminimalisir penelantaran terhadap anak sebagai berikut :

a. Orang tua dituntut kecakapannya dalam mendidik dan menyayangi anak-anaknya. Jangan membiarkan anak hidup dalam kekangan, mental maupun fisik. Sikap memarahi anak habis-habisan, apalagi tindakan kekerasan (pemukulan dan penyiksaan fisik) tidaklah arif, karena hal itu hanya akan menyebabkan anak merasa tidak diperhatikan, tidak disayangi. Akhirnya anak merasa trauma, bahkan putus asa. Penting disadari orang tua bahwa anak dilahirkan ke dunia ini dilekati dengan berbagai hak yang layak didapatkannya. Seorang anak memiliki hak untuk mendapatkan pengasuhan yang baik, kasih sayang, dan perhatian. Anak pun memiliki hak untuk mendapatkan pendidikan yang baik di keluarga maupun di sekolah, juga nafkah (berupa pangan, sandang dan papan). Bagaimanapun keadaannya, tidak wajib seorang anak menafkahi dirinya sendiri, sehingga ia harus kehilangan banyak hak-haknya sebagai anak karena harus membanting tulang untuk menghidupi diri (atau bahkan keluarganya). Siklus kekerasan dapat berkembang dalam keluarga. Individu yang mengalami kekerasan dari orang tuanya dulu, memiliki kecenderungan signifikan untuk melakukan hal yang sama pada anak mereka nanti. Tingkah laku agresi dipelajari melalui pengamatan dan imitasi, yang secara perlahan terintegrasi dalam sistem kepribadian orang tua.

Oleh karena itu penting bagi orang tua untuk menyadari sepenuhnya bahwa perilaku mereka merupakan model rujukan bagi anak-anaknya, sehingga mereka mampu menghindari perilaku yang kurang baik. Peran keluarga terutama orang tua di sini sangatlah penting. Perlindungan dan kasih sayang seharusnya semakin ditingkatkan. Perekonomian yang sulit jangan menjadikan anak sebagai bahan eksploitasi untuk mencari uang. Masa anak masih dalam tahap belajar dan bermain serta mengenal 
lingkungan. Hal tersebut adalah bekal mereka untuk mengahadapi kehidupan yang selanjutnya ketika mereka beranjak dewasa kelak sehingga terpenuhinya Dasar-dasar tanggung jawab keluarga atau orang tua dalam mendidik anak, yaitu:

a. Adanya motivasi atau dorongan cinta kasih yang menjiwai hubungan orang tua dan anak, kasih sayang orang tua yang ikhlas dan murni akan mendorong sikap dan tindakan rela dan menerima tanggung jawab untuk mengorbankan hidupnya dalam memberi pertolongan kepada anaknya.

b. Pemberian motivasi kewajiban moral sebagai konsekwensi kehidupan orang tua terhadap keturunannya, adanya tanggung jawab moral ini meliputi nilainilai spiritual, menurut para ahli bahwa penanaman sikap beragama sangat baik pada masa anak-anak. Karena seorang anak memiliki pengalaman agama yang asli dan mendalam, serta mudah berakar dalam diri dan kepribadiannya, hal tersebut merupakan faktor yang sangat penting melebihi orang lain, karena pada saat ini anak mempunyai sifat wondering (heran) sebagai salah satu faktor untuk memperdalam pemahaman spiritual reality, pada periode ini peranan orang tua sering mengajak anak-anaknya ketempat-tempat ibadah sebagai penanaman dasar yang akan mengarahkan anak pada pengabdian yang selanjutnya, dan mampu menghargai kehadiran agama dalam bentuk pengalaman dengan penuh ketaatan. Dengan demikian, penanaman agama yang dimiliki anak sejak kecil ini betul-betul tertanam dan berkesan pada dirinya.

c. Tanggung jawab sosial adalah bagian dari keluarga yang pada gilirannya akan menjadi tanggung jawab masyarakat, bangsa dan Negara. Tanggung jawab sosial itu merupakan perwujudan kesadaran tanggung jawab kekeluargaan yang dibina oleh darah, keturunan, dan kesatuan keyakinan.

d. Memelihara dan membesarkan anaknya, tanggung jawab ini merupakan dorongan alami untuk dilaksanakan karena anak memerlukan makan, minum dan perawatan agar ia dapat hidup secara berkelanjutan, disamping itu ia bertanggung jawab dalam hal melindungi dan menjamin kesehatan anaknya baik secara jasmaniah maupun rohaniah dan berbagai gangguan penyakit atau bahaya lingkungan yang dapat membahayakan diri anak tersebut. 
e. Memberikan pendidikan dengan berbagai ilmu pengetahuan dan ketrampilan yang berguna bagi kehidupan anak kelak, sehingga bila ia dewasa akan mampu mandiri. ${ }^{6}$

Dengan demikian, terlihat besar tanggung jawab orang tua terhadap anak. Bagi seorang anak, keluarga persekutuan hidup pada lingkungan keluarga tempat dimana ia menjadi diri pribadi atau diri sendiri, keluarga juga merupakan wadah bagi anak dalam konteks proses belajarnya untuk mengembangkan dan membentuk dari dalam fungsi sosialnya.

2. Peran seorang guru dituntut untuk menyadari bahwa pendidikan di negara kita bukan saja untuk membuat anak pandai dan pintar, tetapi harus juga dapat melatih mental anak didiknya. Peran guru dalam memahami kondisi siswa sangat diperlukan. Sikap arif, bijaksana, dan toleransi sangat diperlukan. Idealnya seorang guru mengenal betul pribadi peserta didik, termasuk status sosial orang tua murid sehingga ia dapat bertindak dan bersikap bijak. Sebagaimana peranan guru yang dikemukakan Sadirman adalah sebagai berikut:

a. Informator

Sebagai pelaksana cara mengajar informatif laboratorium, studi lapangan dan sumber informasi kegiatan akademik maupun umum.

b. Organisator

Guru sebagai organisator, pengelola kegiatan akademik, silabus dan lain-lain. Komponen-komponen yang berkaitan dengan kegiatan belajar- mengajar, semua diorganisasikan dengan sedemikian rupa, sehingga dapat mencapai efektivitas dan efesiensi dalam belajar pada diri sendiri.

c. Motivator

Peranan guru sebagai motivator ini penting artinya dalam rangka meningkatkan kegairahan dan pengembangan kegiatan belajar siswa. Guru harus dapat merangsang dan memberikan dorongan serta reinforcement untuk mendinamisasikan potensi siswa, menumbuhkan swadaya (aktivitas) dan daya cipta (kreativitas), sehingga terjadi dinamika di dalam proses belajar mengajar.

d. Inisiator

Guru dalam hal ini sebagai pencetus ide-ide dalam proses belajar. Sudah barang tentu ide-ide merupakan kreatif yang dapat dicontoh oleh siswa.

${ }^{6}$ Binti Maunah, Ilmu Pendidikan, Teras, Yogyakarta, 2009, hal 92 - 100 


\section{e. Transmitter}

Dalam kegiatan belajar guru juga akan bertindak selaku penyebar kebijasanaa pendidikan dan pengetahuan.

\section{f.Fasilitator}

Berperan sebagai fasilitator, guru dalam hal ini akan memberikan fasilitas atau kemudahan dalam proses belajar-mengajar, misalnya saja dengan menciptakan suasana kegiatan belajar mengajar yang sedimikian rupa, sesuai dengan perkembangan siswa, sehingga interaksi belajar mengajar akan berlangsung secara efektif

g.Mediator

Guru sebagai dapat diartikan sebagai penengah dalam kegiatan belajar siswa. Misalnya menengahi atau memberikan jalan keluar kemacetan dalam kegaitan diskusi siswa. Mediator juga diartikan sebagai penyedia media.

h. Evaluator

Ada kecenderungan bahwa peran sebagai evaluator, guru mempunyai otoriatas untuk menilai prestasi siswa dalam bidang akademis maupun tingkah laku sosialnya, sehingga dapat menentukan bagaimana siswa itu berhasil atau tidak ${ }^{7}$.

3. diperlukan kesadaran dan kerjasama dari berbagai elemen di masyarakat untuk turut memberikan nuansa pendidikan positif bagi anak-anak.

Anak-anak kita ini selain bersentuhan dengan orang tua dan guru, mereka pun tidak bisa lepas dari berbagai persinggungan dengan lingkungan masyarakat dimana dia berada. Untuk itu diperlukan kesadaran dan kerjasama dari berbagai elemen di masyarakat untuk turut memberikan nuansa pendidikan positif bagi anak-anak kita ini. Salah satu elemen tersebut adalah pihak pengelola stasiun TV. Banyak riset menyimpulkan bahwa pengaruh media (terutama TV) terhadap perilaku anak (sebagai salah satu penikmat acara TV) cukup besar. Berbagai tayangan kriminal di berbagai stasiun TV, tanpa kita sadari telah menampilkan potret-potret kekerasan yang tentu akan berpengaruh pada pembentuk mental dan pribadi anak. Penyelenggara siaran TV bertanggungjawab untuk mendesain acaranya dengan acara yang banyak mengandung unsur edukasi yang positif.

\footnotetext{
${ }^{7}$ Sardiman, Interaksi Motivasi Belajar Dan Mengajar, Rajawali Press, Jakarta, 2011, Hal. 144
} 
4. Pemerintah adalah pihak yang bertanggung jawab penuh terhadap kemaslahatan rakyatnya, termasuk dalam hal ini adalah menjamin masa depan bagi anak-anak kita sebagai generasi penerus. Pemerintah harus memberikan ketegasan pada masyarakat Tentang Perlindungan Anak, bila perlu memberikan sosialisasi bahwa ada Undang-Undang bertujuan dalam perlindungan anak serta dijelaskan juga sanksi terhadap yang melanggar Undang-Undang tersebut. Pemerintah juga harus memberikan fasilitas pelatihan dan pembelajaran anak. Maka pemerintah harus siap menampung anak-anak yang terlantar sesuai dengan bunyi UUD 1945 pasal 34 ayat 1, "Fakir miskin dan anak-anak terlantar dipelihara oleh negara".

\section{E. Kesimpulan}

1. Kebijakan perlindungan hukum terhadap anak korban penelantaran oleh orang tua menurut persfektif Hukum Indonesia adalah peraturan-peraturan yang dibuat oleh Pemerintah yang bertujuan memberikan perlindungan hukum. Adapun peraturan peraturan dimaksud adalah Kitab Undang Undang Hukum Pidana (KUHP), Undang Undang Nomor 4 Tahun 1979 tentang Kesejahteraan Anak, Undang Undang Nomor 39 Tentang Hak Asasi Manusia, Undang Undang Nomor 23 Tahun 2004 Tentang Penghapusan Kekerasan Dalam Rumah Tangga, Undang Undang Nomor 35 Tahun 2014 tentang Perubahan Atas Undang Undang 23 Tahun 2002 Tentang Perlindungan Anak. Perlindungan Hukum Terhadap Anak Korban Penelantaran Oleh Orang Tua di dalam KUHP, terdapat lima Pasal yaitu pasal 304, 305, 306, 307, 309. Menurut Undang Undang Nomor 4 Tahun 1979 tentang Kesejahteraan Anak, dimana didalam Undang Undang ini diatur hak-hak anak, tugas dan tanggung jawab sebagai orang tua terhadap anak-anak mereka dan peranan Pemerintah mengadakan pengarahan, bimbingan, bantuan, dan pengawasan terhadap usaha kesejahteraan anak yang dilakukan oleh masyarakat. Menurut Undang Undang Nomor 39 Tentang Hak Asasi Manusia, dimana Anak adalah setiap manusia yang berusia di bawah 18 (delapan belas) tahun dan belum menikah, termasuk anak yang masih dalam kandungan apabila hal tersebut adalah demi kepentingannya (Pasal 1 Angka 5) yang memiliki asas-asas dasar sebagai hak asasi manusia yang diakui dan dijunjung oleh Negara Republik Indonesia sebagai hak yang secara kodrati melekat pada dan tidak terpisahkan dari manusia, yang harus dilindungi, dihormati, dan ditegakkan demi peringatan martabat kemanusiaan, kesejahteraan, kebahagiaan, dan kecerdasan serta keadilan (Pasal 2). 
Dalam rangka penegakan hak asasi manusia, perbedaan dan kebutuhan dalam masyarakat hukum adat harus diperhatikan dan dilindungi oleh hukum, masyrarakat, dan pemerintah (Pasal 6 ayat (1)) menjadi tanggung jawab pemerintah (Pasal 8). Menurut Undang Undang Nomor 23 Tahun 2004 Tentang Penghapusan Kekerasan Dalam Rumah TanggaDimana anak merupakan bagian dari lingkup keluarga dan dilarang melakukan kekerasan terhadap anak (Pasal 2) dan pengaturan sanksi pidana bagi pelaku yang melakukan kekerasan terhadap anak, diketahui bahwa penelantaran anak oleh orang tua merupakan wujud kekerasan yang dapat berdampak fisik maupun psikis (Pasal 44 dan 45). penelantaran anak didalam Undang Undang Nomor 35 Tahun 2014 termasuk kedalam tindakan kekerasan terhadap anak (Pasal 15a) dan bagi pelaku penelantaran (orang tua) mendapatkan sanksi hukuman sebagaimana dicantumkan dalam Pasal 77B dan 80.

2. Analisa yuridis perlindungan hukum terhadap anak korban penelantaran oleh orang tua di Indonesia belum optimal dikarenakan kasus penelantaran anak oleh orang tua masih meningkat. Hal ini disebabkan oleh masih lemahnya system hukum yang terdiri dari komponen Struktur, Substansi, dan kultur yang tidak dapat saling bekerjasama pelaksanaan perlindungan hukum terhadap korban anak. Kendala-kendala yang dihadapi antara lain : Keterbatasan kemampuan untuk menempatkan diri dalam peranan pihak lain dengan siapa dia berinteraksi, tingkat aspirasi yang relative belum tinggi, kegairahan yang sangat terbatas untuk memikirkan masa depan sehinga sulit sekali untuk membuat suatu proyeksi, belum adanya kemampuan untuk menunda pemuasan suatu kebutuhan tertentu terutama kebutuhan material, kurangnya daya inovatif yang sebenarnya merupakan pasangan konservatisme (Aspek Struktural), belum adanya peraturan pelaksanaan yang sangat dibutuhkan untuk menerapkan undang-undang, ketidak jelasan arti kata-kata didalam undang-undang yang mengakibatkan kesimpang siuran di dalam penafsiran dan penerapannya orang tua sendiri yang merupakan pelaku penelantaran (Aspek Substansi), kebanyakan keluarga yang tidak melaporkan kasus ini karena apabila kasus ini tersebar, maka hanya akan menjadi aib bagi keluarga, Sulitnya mendapat keterangan yang sebenar-benarnya dari korban anak, apabila ada orang tua di sisinya, adanya intervensi dari pihak keluarga yang mengintimidasi si Anak sehingga kasus ini seperti ditutup tutupi, kesulitan dalam Reintegrasi, hal ini dikarenakan orang tua tidak mau menerima anak itu kembali di 
dalam keluarga. Hal ini disebabkan kekecewaan orang tua yang merasa anaknya telah mencemari nama baik keluarga (Aspek Kultur).

\section{F. Rekomendasi}

1. Meningkatkan peranan pemerintah Negara, Pemerintah, Pemerintah Daerah, Masyarakat, Keluarga, dan Orang Tua atau Wali berkewajiban dan bertanggung jawab terhadap penyelenggaraan Perlindungan Anak Dilakukan

2. Sosialisasi simultan terhadap penerapan Undang Undang Nomor 35 Tahun 2014 dikarenakan penetapan Undang Undang ini merupakan penyesuaian terhadap beberapa ketentuan dalam Undang-Undang Nomor 23 Tahun 2002 tentang Perlindungan Anak dalam memberikan perlindungan hukum terhadap anak sehingga tercapai kesejahteraan terhadap anak

\section{G. Daftar Pustaka}

Nursyamsiyah Yusuf, Ilmu Pendidikan, Pusat Penerbitan dan Publikasi, Tulung Agung, 2000,

Binti Maunah, Ilmu Pendidikan, Teras, Yogyakarta, 2009,

Abu Huraerah, Kekerasan Anak Terhadap Anak, Nuansa, Bandung, 2006

Soerjono Soekanto, Pengantar Penelitian hukum, Jakarta, UI PRESS, 1986

Soerjono Soekanto dan Sri Mamuji, Penelitian Hukum Normatif "Suatu Tinjauan Singkat", Jakarta, PT Raja Grafindo Persada, 2004

Harkristuti Harkrisnowo, Reformasi Hukum: Menuju Upaya Sinergistik Untuk Mencapai Supermasi Hukum yang Berkeadilan, Jurnal Keadilan Vol. 3, No. 6 Tahun 2003/2004.

Sardiman, Interaksi Motivasi Belajar Dan Mengajar, Rajawali Press, Jakarta, 2011 